\title{
Ligula intestinalis (Cestoda: Pseudophyllidea): an ideal fish-metazoan parasite model?
}

\author{
D. HOOLE ${ }^{1 *}$, V. CARTER ${ }^{1}$ and S. DUFOUR ${ }^{2}$ \\ ${ }^{1}$ School of Life Sciences, Huxley Building, Keele University, Keele, Staffordshire, ST5 5BG, UK \\ ${ }^{2}$ UMR BOREA Biologie des Organismes et Ecosystèmes Aquatiques, CNRS 7208/IRD 207//MNHN/UPMC Musèum \\ National d'Histoire Naturelle, 7 rue Cuvier, 75231 Paris cedex 05, France
}

(Received 7 August 2009; revised 5 Fanuary and 7 Fanuary 2010; accepted 7 Fanuary 2010; first published online 18 February 2010)

\begin{abstract}
SUMMARY
Since its use as a model to study metazoan parasite culture and in vitro development, the plerocercoid of the tapeworm, Ligula intestinalis, has served as a useful scientific tool to study a range of biological factors, particularly within its fish intermediate host. From the extensive long-term ecological studies on the interactions between the parasite and cyprinid hosts, to the recent advances made using molecular technology on parasite diversity and speciation, studies on the parasite have, over the last 60 years, led to significant advances in knowledge on host-parasite interactions. The parasite has served as a useful model to study pollution, immunology and parasite ecology and genetics, as well has being the archetypal endocrine disruptor.
\end{abstract}

Key words: L. intestinalis, endocrine disruption, pollution, immunology, parasite ecology, parasite speciation.

\section{THE PARASITE}

There is perhaps no other metazoan parasite that evokes such awe and revulsion within the fishing fraternity world-wide than the plerocercoid stage of the pseudophyllidean cestode, Ligula intestinalis. This is primarily due to the impressive size which this parasite can obtain in the body cavity of its fish intermediate host, and yet it is the size of the parasite and its relationship with its fish host which has made this parasite such a valuable model to study parasite/host interactions at the molecular, cellular, organismal and population levels. As a highlight of the size which the infection can attain, Barus and Prokes (1994) noted that the weight of parasite tissue can be greater than that of the fish tissue (Fig. 1). This relationship has been studied utilising the parasitisation index (parasite weight/fish weight $\times$ 100) which normally lies in the range of $1-20 \%$ (Claridge et al. 1985) or up to $40 \%$ as recorded by Morrison (1977). It is perhaps not surprising therefore that the infection has been associated with a distension of the body wall which leads to separation of the scales which may allow entry of pathogens (e.g. Sweeting, 1977), and effects on the body wall and musculature (Richards and Arme, 1981; Loot et al. $2001 c$ ). In some rare instances, perforation of the body wall and intrusion of the parasite into the

* Corresponding author: School of Life Sciences, Huxley Building, Keele University, Keele, Staffordshire, ST5 5BG, UK. Tel: + 44 (0)1782 733673; Fax: + 44 (0)1782 733516; E-mail:d.hoole@biol.keele.ac.uk aquatic environment has been noted (e.g. Barus et al. 1997). The authors proposed that this may represent a possible means for a free-living phase of the plerocercoid or, at least, prolong the window for transmission into a definitive host for several days after death of the host.

The plerocercoid of L. intestinalis occurs in a wide range of fish hosts. In Europe it has been found in several species of cyprinids, e.g. roach (Rutilus rutilus), rudd (Scardinius erythrophthalmus), dace (Leuciscus leuciscus), gudgeon (Gobio gobio), bream (Abramis brama), bleak (Alburnus alburnus), minnow (Phoxinus phoxinus), chub (Leuciscus cephalus), tench (Tinca tinca) and silver bream (Blicca bjoerkna) (Orr, 1968; Arme and Owen, 1968; Harris and Wheeler, 1974; Adamek et al. 1996; Museth, 2001; Loot et al. $2001 a, b, c, d, 2002 a, b, 2006$; Hecker et al. 2007). Dubinina (1966) noted 49 species of fish in the former USSR were hosts of the parasite, whilst there are several authors who have indicated the presence of the worm in the North American continent. For example, in Canada, Szalai et al. (1989) noted the parasite in white suckers (Catostomus commersoni), yellow perch (Perca flavescens), quillback (Carpoides cyprinus) and spottail shiners (Notropis hudsonius), and Groves and Shields (2001) and Shields et al. (2002) found the parasite in the Crooked River system and Haystack Reservoir in central Oregon. Ligula has also been found in the Middle East (Ergonul and Altindag, 2005 $a, b$; Sasi, 2005; Kir and Tekin-Ozan, 2005; Hatice et al. 2006; Shargh et al. 2008; Hajirostamloo, 2008; Aydogdu et al. 2008; Tekin-Ozan and Kir, 2008), 


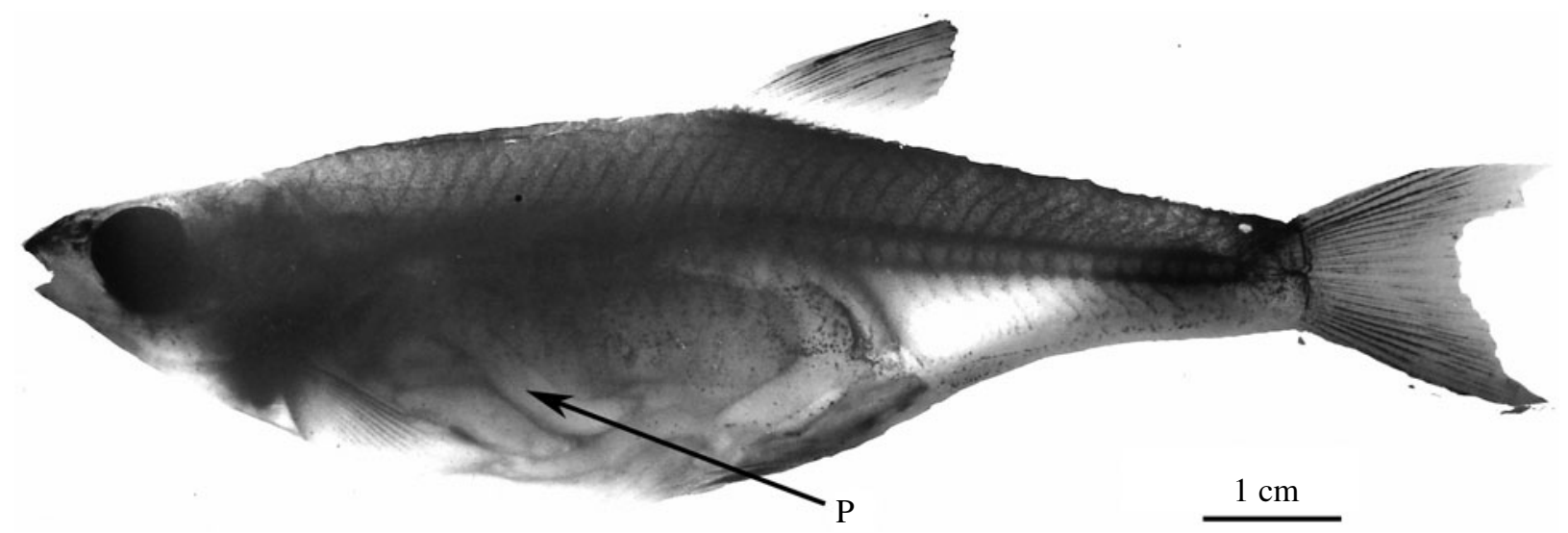

Fig. 1. Ligulosed roach, Rutilus rutilus, fixed in Bouins fixative and cleared in xylene. Note plerocercoid burden (P) within the body cavity of the fish host. (Picture reproduced by kind permission of Professor C. Arme, Keele University, UK.)

Africa (Dejen et al. 2006; Cowx et al. 2008; Britton et al. 2009) and Australasia (Pollard, 1974; Weekes and Penlington, 1986; Morgan, 2003). In China, the parasite can cause problems in culture systems (Xianghua and Zhixin, 1987; Li and Liao, 2003). The large range of fish species that the parasite has been recorded from is also extended to the association between the definitive host and the adult parasite, for example, Dubinina (1966) claimed 72 species of bird can serve as final hosts for the Ligulidae. Dubinina has also given an account of the development cycle of Ligula in which parasite eggs, which first appear in the uterus 45-50 hours after infection, pass out in the birds' faeces and hatch after 5-8 days to release the free-swimming coracidia. These are ingested by the copepod first intermediate host in which the procercoid develops, and the fish becomes infected by consuming the infected copepod. The ubiquitous nature of Ligula in terms of host fish and geographical range has meant that this parasite has been a good model to study speciation and diversity in fish parasites.

\section{LIGULA AS AN ECOLOGICAL MODEL}

Although there have been numerous studies on the ecological interactions between fish parasites and their hosts, the majority have concentrated on limited time spans with, on some occasions, speculation on the long-term implications of infection. None of the studies undertaken, except some of those carried out on Ligula, have considered what happens to the epizootic and the implications for the aquatic community over an extended time period. Although some studies (Bauer and Stolyarov, 1961; Black and Fraser, 1984; Izyumova, 1987) have revealed that Ligula may persist for several years within a single water body, the majority of studies, for example those carried out in the UK (Wilson, 1971; Sweeting, 1976; Morrison, 1977; Tobin, 1986; Bean and Winfield, 1992), have noted that a decline of fish host populations leads to reduction in transmission rates of the parasite. This reduction is thought to be due primarily to an increase in fish mortality in infected fish caused by either a reduction in their ability to survive over winter (Wyatt and Kennedy, 1988) and/or by making the infected fish more susceptible to predation both by birds and fish (Van Dobben, 1952; Holmes and Bethel, 1972; Sweeting, 1976; Hoole, 1994). Studies on metazoan parasite/host systems in natural environments are invariably, due to funding restrictions or available opportunities, restricted to short time periods. The effects of Ligula on host populations noted above make this parasite a unique model to study long-term effects of parasitisation on host dynamics. This has been achieved by several eloquent studies carried out by Kennedy and co-workers over a period of 31 years utilising Ligula infections in Chew Lakes, Slapton Ley, Devon, UK (Kennedy et al. 2001). The events that pre-disposed the lake for introduction of Ligula began in the 1960 s when increasing eutrophic conditions and an expansion of the roach population led to intra-specific competition and the presence of numerous small, stunted roach and a decline in the dominant rudd population. This change in the fish population dynamics and availability of an ample small sized food source attracted Great Crested Grebes, Podiceps cristatus, one of the definitive hosts for L. intestinalis and it was not surprising to note the appearance of ligulosed roach in 1973. The prevalence peaked at $28 \%$ in 1975 and resulted in a decline in the roach population and a subsequent recovery in the rudd numbers. This was the first cycle of Ligula infection whose details were described by Burrough and Kennedy (1979), Kennedy and Burrough (1981) and Wyatt and Kennedy (1988, 1989). The decrease in roach numbers led to increased growth rates, but adverse winter conditions during 1984-1985 caused substantial fish deaths and the parasite re-appeared in 1991 in the 1989, 1990 and 1991 year classes. In this second wave of infection, prevalence levels were 
very high i.e. $75 \%$ peaking in 1992. A decline in infection occurred between 1993-1994. It would appear that a third cycle also occurred from 1999 and although infection occurred in 0,1 and 2 year old fish, prevalence never exceeded $14 \%$. The studies on Slapton Ley are therefore unique, not only in their duration, but also in the fact that 3 distinct infection cycles were clearly observed although this does not imply any regulation or stability within the system as infection cycles varied. In previous shortterm studies (Arme and Owen, 1968; Harris and Wheeler, 1974; Sweeting, 1976, 1977; Bean and Winfield, 1992), biotic factors such as fish feeding behaviour and copepod levels were suggested to affect Ligula predominance in smaller fish. In contrast, in the second cycle at Slapton Ley, fish of all ages may have been infected. Kennedy et al. (2001) proposed that whilst the long-term study may suggest controlled population regulation, the first and second cycles were in fact independent events and the cycles reflect changes in habitat. Recently Ligula intestinalis has proved an invaluable model to elucidate how parasites may modify their host phenotypic appearance, and the impact that this has on the ecological interactions between parasites and their hosts, and transmission success. In 1999, Lafferty defined a phenomenon which resulted in an increase in parasite fitness mediated by evolutionary processes, the so-called 'Parasite Increased Trophic Transmission-PITT'. Extensive studies carried out since 2000 by Loot and co-workers on ligulosed roach populations in France have made a significant contribution to testing the PITT hypothesis in natural systems. Detailed morphological investigations on roach collected from the LavernoseLacasse gravel pit complex in Toulouse revealed that extensive morphological changes occurred in ligulosed roach which were dependent on total parasite biomass (Loot et al. 2001c). Further studies by Loot et al. (2001d) showed that in the Lavernose, Muret and Pareloup lake systems the distribution of the plerocercoid of L intestinalis was spatially and temporally clumped within their fish hosts although this aggregation was far more pronounced in the Lavernose Lake suggesting the presence of siterelated affects. Loot and co-workers (2001 $a$ ) also noted that ligulosed roach were more highly parasitised closer to the bank and that parasite occurrence and abundance were both highly significant parameters in accounting for this spatial distribution. They also showed that these two parameters decreased in fish older than 3 years of age, suggesting that Ligula infection resulted in host death. Three hypotheses were considered to explain why parasite infection was greatest near the bank of the lake. Whilst the possibilities that this infection distribution was due to an accidental side-effect of parasitisation or perhaps was correlated to the localisation of infected first intermediate copepod hosts were considered, the authors proposed that Ligula increased feeding motivation into the highly productive littoral areas of the lake and the reduced swimming efficiency increased predation by the bird definitive host. These results thus support the PITT hypothesis. Detailed studies on the interaction between L. intestinalis and its fish host have primarily concentrated on the Euro-Mediterranean clades and it is only recently that the PITT hypothesis has been investigated in other geographical localities. Britton et al. (2009) investigated Ligula host specificity in the fish population of Lakes Baringo and Naivasha in Kenya's Rift Valley. It was noted that the parasite had a restricted second intermediate host range occurring in two cyprinid fish species, Barbus lineomaculatus and B. paludinosus, and, in comparison to the Euro-Mediterranean clade, multiple infections were not observed frequently. The authors suggested that since parasite prevalence was correlated to habitat the results obtained could be interpreted as supportive of the PITT hypothesis. The complex life cycle of $L$. intestinalis has also recently been utilised to establish the contributing role that host ecological dynamics and physiological compatibility has on parasite transmission and evolution. Loot et al. (2006), using measurements of host abundances over time, noted that in the Lavernose-Lacasse gravel pit system used in earlier studies, the favoured Ligula hosts were the copepod, Eudiaptomus gracilis, the roach Rutilus rutilus and the great crested grebe (Podiceps cristatus). It was suggested that the similar temporal dynamics and frequent associations between hosts and parasite created a stable system that promoted the successful completion of the Ligula life cycle. Such an association, it was proposed, affected the evolution of L. intestinalis specificity. It was hypothesised that the selection of hosts was driven by the probability of successive hosts encountering each other which aided parasite transmission and whilst, biochemical compatibility between host and parasite was important, this may be secondary to spatial and temporal dynamics.

There have been extensive studies on the pathological and biochemical interactions between Ligula and its fish hosts (for example see Arme et al. 1982; Hoole, 1994) which have primarily been stimulated by the large parasite burdens that can occur in some hosts and the subsequent extensive size that infected hosts can attain. The possibility that host gigantism occurs in Ligula infection has thus been recently investigated by Loot et al. (2002b) who revealed that the parasite induced an enhanced growth rate during the first 2 years of the life of the roach host. Whilst the possibility that the parasite produced growth enhancers or may divert energy from gonadal development to somatic growth were considered, the authors proposed that since cestode-associated growth in the heaviest infected fish was only found in one out of the three localities studied, that the 


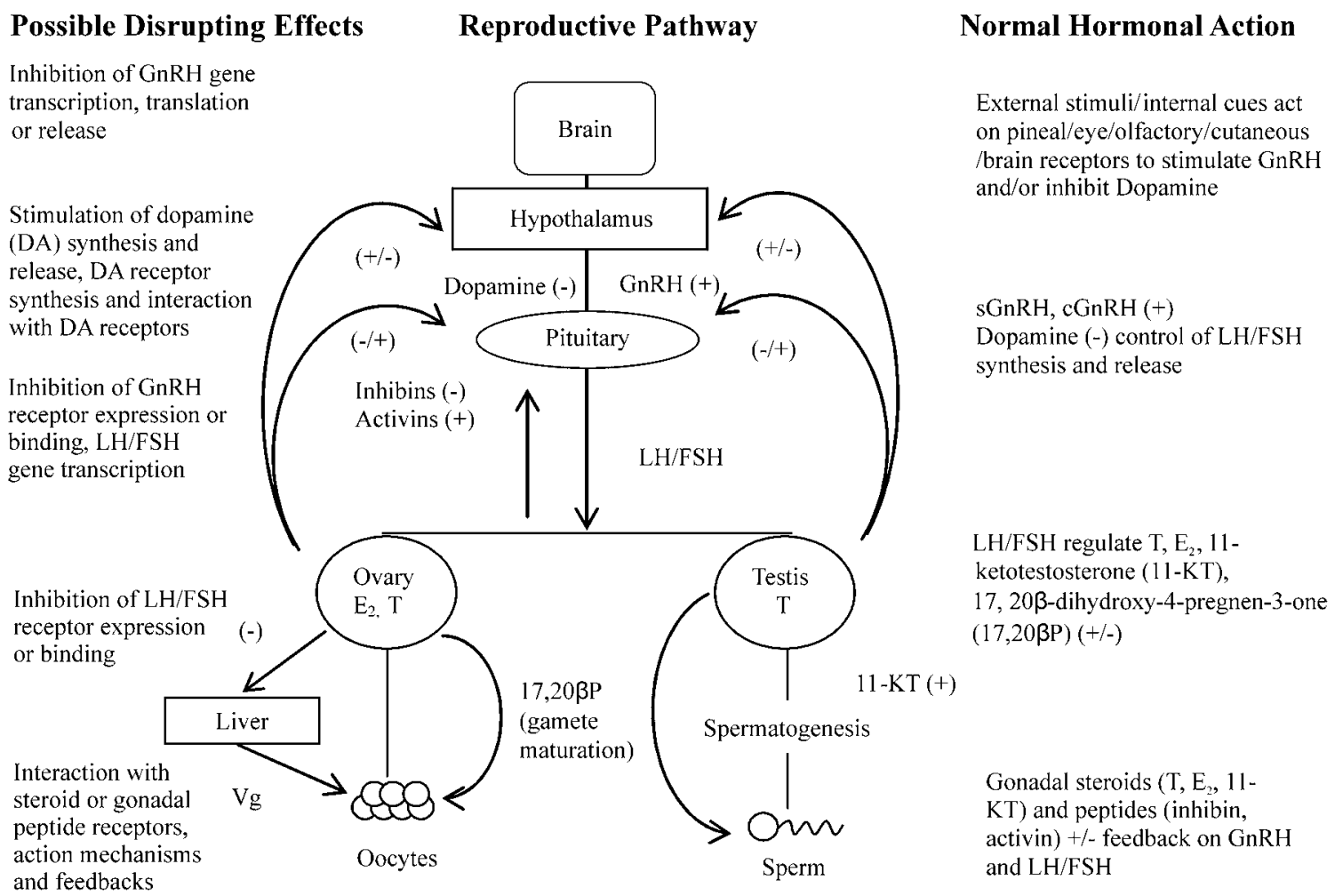

Fig. 2. Possible actions of Ligula on the roach reproductive pathway, $+=$ stimulation, $-=$ inhibition.

effect may result from a change in foraging behaviour of the fish. What these and other studies have highlighted however is the intricate association between Ligula and the reproductive potential of its fish host.

\section{LIGULA: THE MODEL OF ENDOCRINE DISRUPTION}

Perhaps the most significant impact of Ligula on the fish host population is its ability to inhibit reproductive function of its host. Whilst it has been established previously that parasite effects on host reproduction occur in several host/parasite interactions, for example the snail, Lymnea stagnalis infected with Trichobilharzia ocellata (Joose and van Elk, 1986); Schistosoma mansoni infections of Biomphalaria glabrata (Crews and Yoshino, 1989) and in vertebrate hosts - the tapeworms Taenia taeniaeformis affect the testis in rats and T. crassiceps induces feminisation in mice (Lin et al. 1990; Larralde et al. 1995, respectively) - it is the intricate relationship between Ligula and the reproductive endocrine status of the fish that has fascinated and perplexed biologists. Studies by Kerr (1948) and Arme (1968) noted that in ligulosed roach, putative gonadotrophs were reduced in number and had a reduced granular content than their uninfected counterparts. This effect on reproductive potential has been reported subsequently by Arme and Owen
(1968), Mahon (1976), Sweeting (1977), Bean and Winfield (1989) and Cowx et al. (2008) and has driven the idea that the effect of Ligula on reproductive inhibition is mediated through the host's pituitary gland. The effects of the parasite on the pituitary gland were observed 6 weeks postimplantation of a small worm into a mature female roach and also occurred in non-host species such as Xenopus laevis (Arme, 1968, 1975). These observations not only indicate that the effects on the pituitary gland may not be dependent on worm burden, but suggest a general endocrine effect rather than an inhibition which is species specific. The mechanism by which this effect is mediated is unknown, but is thought to be via the hypothalamus/ pituitary gland/gonadal axis. This axis is a complex array of hormones and feedback mechanisms, any number of which could be affected by Ligula (Fig. 2). To understand the possible intricate effects of Ligula on fish reproduction thus requires a brief consideration of the complexity that is the reproductive endocrine control mechanism in fish. Gonadotrophin Releasing Hormone $(\mathrm{GnRH})$ is regarded as the first key hormone in the cascade controlling reproduction. GnRH occurs in a variety of forms which are thought to have arisen from gene duplication and mutations (O'Neill et al. 1998; Okubu and Aida, 2001) and interacts with receptors present on the pituitary gonadotrophs. The expression of these receptors dictates the sensitivity of the pituitary to 
the GnRH, as increased receptor numbers at spawning enhance the preovulatory gonadotrophin surge (Yu et al. 1998). During the reproductive cycle, the GnRH content in the hypothalamus and pituitary gland of goldfish increases to a maximum on the day of aggregation for spawning and is lowest in preovulatory and immature fish.

As revealed by the pioneer studies of R.E. Peter and coworkers in the goldfish, pituitary gonadotropic cells of teleosts may be subjected to regulation, not only by a stimulatory control of GnRH as in mammals, but also as direct inhibition by dopamine (for review see Peter et al. 1986). GnRH and dopamine are, respectively, the principal stimulatory and inhibitory neurohormones controlling gonadotrophin release (e.g. Hernandez-Rauda et al. 1996; Trudeau, 1997). In the goldfish, dopamine was shown to be involved in the inhibition of the final steps of gametogenesis in mature fish (final oocyte maturation and ovulation in females, spermiation in males), a role that was also found in the other cyprinids studied, as well in other, but not all, teleost species (for review see Dufour et al. 2005). The possible inhibitory role of dopamine in the inhibition of earlier steps of gametogenesis was investigated in the European eel, in which a strong dopaminergic inhibition was shown to be involved in the prepubertal blockade of sexual maturation, before the oceanic reproductive migration (Vidal et al. 2004; Dufour et al. 2005). A dopaminergic role in the inhibition of puberty was also recently found in the mullet (Nocillado and Elizur, 2008) but not in some other teleost species such as the striped bass or seabream (for review: Dufour et al. 2005). This complexity thus gives Ligula a range of potential strategies to affect the endocrine status and reproduction of its fish host.

The gonadotrophic hormones, synthesised and released from the anterior pituitary gland have a controlling role on reproduction. GtHI (FSH) mediates gonadal growth (Tyler et al. 1999), whilst GtHII ( $\mathrm{LH})$ regulates the final stages of maturation and ovulation/spermiation. These gonadotrophins act primarily on the ovary and testes to promote gametogenesis. Receptors for $\mathrm{GtH}$ are located in both cell layers surrounding the oocytes (thecal and granulosa cells) and in the testis (Kanamori et al. 1987; Yan et al. 1992). Fish gonads have the capacity to synthesise steroid hormones such as $17 \beta$-estradiol, testosterone, 11-KT and 17-20 $\beta \mathrm{P}$ (Nagahama, 1999), as well as gonadal peptides (inhibin, activin) which exert feedback control onto the hypothalamus and pituitary gland in a classical feedback loop, and their regulation is dependent on the maturational status of the fish (Feist and Schreck, 1996). Ligula could therefore be affecting the secretion of GtH hormones, their receptors and/or the feedback system between the gonads and the brain. Indeed, the fact that fish usually become infected when young may suggest that the parasite is preventing puberty in its host. Ligula could therefore be considered as a useful tool to gain an understanding of the endocrine control of the development of the reproductive system as it could mediate its effect at various levels in the hypothalamus/pituitary gland/gonadal axis (Fig. 2).

Implantation of Ligula plerocercoids into uninfected roach results in atresia of developed follicles, or if implanted after ovulation, inhibited recrudescence in fish examined 3 months after implantation (Arme, 1968). The effects are reproducible with a small plerocercoid implanted into a large mature fish, which precludes pressure effects on fish organs or general debilitation from parasite metabolic demands (Arme, 1975). Arme postulated that Ligula produces a substance with an inhibitory effect on the pituitary gland, and noted that the nature of the substance was similar in action to testosterone treatment and may possibly be a steroid with anti-gonadal effects on the pituitary gland. Arme et al. (1982) later published evidence against this hypothesis as three different assay attempts failed to identify a sex steroid in extracts of worm and in media in which the parasites had been cultured, although cholesterol (sex steroid precursors) was identified in abundance (Arme, 1997). It is plausible that Ligula targets GnRH as two forms of gonadotrophin releasing hormone (sGnRH and cGnRH-II) have been localised in brains of ligulosed and uninfected roach by Penlington et al. (1997). Although no differences in cell distribution, cell number or staining intensity were detected that could be attributed to Ligula, both GnRH forms were present in uninfected and infected fish, although cGnRH positive neurones were more numerous than $\mathrm{sGnRH}$ (Williams et al. 1998).

Endocrine studies by Carter et al. (2005) have revealed a more intricate effect of Ligula on the endocrine status of the pituitary gland in roach. The effect of parasitisation on the $\mathrm{LH}$ content of this gland was studied using heterologous radioimmunoassay for the $\mathrm{LH} \beta$ subunit of Cyprinus carpio which revealed that the pituitary gland of infected roach contained $50 \%$ less $\mathrm{LH}$ than non-ligulosed fish. In addition, partial cloning of roach $\mathrm{LH} \beta$ subunit allowed Carter and co-workers to show that there was a $50 \%$ reduction in $\mathrm{LH} \beta \mathrm{mRNA}$ in the pituitary gland of ligulosed roach. These results support the hypothesis that the pituitary gland plays a significant role in the interaction between the parasite and the reproductive status of the fish host. There is evidence however that the interaction between Ligula and the brain of fish may be multifaceted. Testosterone can have a two-fold effect on the regulation of $\mathrm{LH}$ transcript levels either in its own right (Huang et al. 1997) or after aromatisation in the pituitary to $\mathrm{E}_{2}$ in order to stimulate $\mathrm{LH}$ (Antonopoulou et al. 1999). Aromatase activity, 
which is seasonally present in the pituitary of the goldfish (Melamed et al. 1998), as in all vertebrates, is a member of an enzyme complex including P450 aromatase and reductase which carries out the conversion of androgens to estrogens (Gonzalez and Piferrer, 1999; Carreau et al. 2002). This essential enzyme complex for estrogen biosynthesis has been demonstrated in the brain and ovary of teleosts (Cruz and Canario, 1999). Stimulatory effects of small quantities of testosterone are consistent with a positive feedback mechanism, which stimulates accumulation and secretion of LH. Large testosterone doses presumably exert negative effects via inhibition of LH (Berglund et al. 1995). Recent studies by Hecker et al. $(2005,2007)$ have further investigated the role of aromatase activity in the control of endocrine status in Abramis brama from the river Elbe in Germany. Brain aromatase activity was significantly positively correlated with plasma estradiol in females and 11-ketotestosterone in males which the authors suggested led to the disruption of reproductive parameters such as the maturation of germ cells and secondary sex characteristics. The interesting observation was that the prevalence of Ligula in the fish was correlated with a suppression of the aromatase activity.

Further studies are also required to investigate the possible impact of the parasite on the expression and production of roach FSH. Indeed, according to data in other teleosts, FSH is supposed to be mostly involved in the control of the first steps of gametogenesis (vitellogenesis in the female, spermatogenesis in the male) while LH would control the last ones (oocyte final maturation and ovulation in the female, spermiation in the male). Recently, Trubiroha et al. (2009) developed quantitative real time PCR to evaluate the impact of Ligula on the expression of $\mathrm{LH} \beta$ and $\mathrm{FSH} \beta$ subunits in infected roach. In agreement with the authors' previous studies (Carter et al. 2005), field studies revealed a significant decrease in both $\mathrm{LH} \beta$ and $\mathrm{FSH} \beta$ pituitary expression in infected roach as compared to non-infected ones. However, under controlled laboratory condition of infection, only $\mathrm{FSH} \beta$ mRNA levels were lowered. This suggested that FSH may be a prime target of Ligula inhibitory effect on roach sexual maturation, in agreement with the early role of FSH in the induction of gametogenesis as discussed above. Considering the early blockade of sexual maturation by Ligula in the roach, development of new tools such as the use of reproductive cell lines to investigate the regulation of FSH expression and release would be highly relevant.

The possibility that Ligula is producing a substance that directly affects pituitary gland activity has been investigated in unpublished studies carried out by the authors using a pituitary primary cell culture system (PPCC) according to the method previously developed (Montero et al. 1996; Huang et al. 1997).
Pituitary glands cells obtained from female silver (prepubertal) eels (Anguilla anguilla) were exposed to secretions (WCM) from Ligula intestinalis and LH content measured by radioimmunoassay (Dufour et al. 1983). Ligula WCM added to eel pituitary cells induced a significant increase in cellular LH content which occurred in a dose-dependent manner $(0.658 \mu \mathrm{g}-1.8 \mu \mathrm{g}$ of Ligula protein). Whilst the presence of protease inhibitors did not affect the amount of LH produced when pituitary cells were exposed to whole parasite WCM, it did increase the LH content of the pituitary cells exposed to parasite fractions (e.g. $30+\mathrm{kDa}$ fraction with protease inhibitors $=412 \cdot 8 \pm 29 \mathrm{ng} \mathrm{LH} / \mu$ l cell extract, without protease inhibitors $=20 \cdot 25 \pm 1 \mathrm{ng} \mathrm{LH} / \mu 1$ cell extract, $\mathrm{T}=13 \cdot 6, P<0 \cdot 001$ ), which suggests that this endocrine active substance is susceptible to proteolytic digestion. Indeed, there are previous reports which indicate that Ligula plerocercoids not only produce proteolytic enzymes, but also protease inhibitors (Matskasi and Juhasz, 1977; Juhasz, 1979; Matskasi and Nemeth, 1979). The protective effect of protease inhibitors was also observed on the effects of other fractions of parasite secretions (e.g. $10-30 \mathrm{kDa}$, $3-10 \mathrm{kDa}$ or $<3 \mathrm{kDa}$ ) on the LH content of pituitary cells, which suggests that multiple factors secreted by Ligula may contribute to the endocrine disruption of the host reproduction.

Although the eel pituitary cell culture model adopted indicated a possible direct effect of Ligula on pituitary gland cells, a method of maintaining pituitary cells from the natural host of Ligula, the roach, failed to give any conclusive results. The increase in LH content measured on addition of parasite products to the eel pituitary cell model may be due to several possible mechanisms, such as an increase in production of $\mathrm{LH}$ and a decrease in the release of LH from the pituitary gland, or no change in $\mathrm{LH}$ production, but a decrease in $\mathrm{LH}$ release. The effect of Ligula on eel pituitary cells also supports the previous suggestion by Arme (1968) that effects of this parasite on host reproduction may not be limited to its natural host. Further studies should aim at investigating the possible direct effects of Ligula products on the expression of roach $\mathrm{LH} \beta$ and FSH $\beta$ subunits.

Whilst there appears to be much debate on the mechanism by which Ligula affects the reproductive status of its fish host there appears to be a consensus, at least in the speculation, as to why this should occur and how the parasite might benefit from this effect. Besides the possible effects on the energy balance in the infected fish several authors e.g. Barber and Huntingford (1996), Loot et al. (2001a, $2002 a, b$ ), Morgan (2003), Dejen et al. (2006) have proposed that infection in fish leads to altered behaviours such as movement to shallow waters, occurrence of fish on the surface of the water, swimming impediments, absence of shoaling, and 
delayed response to a stimulus, all of which lead to the infected fish being more prone to predation by the avian definitive host or another fish (Museth, 2001). This host/parasite interaction thus has an important role to play in the studies on the parasite manipulation and predator foraging behaviour (Brown et al. 2001, 2002; Fenton and Rands, 2006).

Parasitism, and in particular with Ligula, is not the only biological factor which can affect the endocrine system and over the last 25 years there have been many studies (e.g. McMasters et al. 1996; Harries et al. 1997, 1999) which have shown that chemical pollutants can affect the endocrine status of fish. Surprisingly, there are very few studies that have considered water quality in association with the Ligula/fish interaction. Recent investigations by Hecker and co-workers (Hecker and Karbe, 2005; Hecker et al. 2007) on Abramis brama infected with L. intestinalis collected from the river Elbe have attempted to relate endocrine status of the fish to parasitisation and the presence of a range of chemicals from industrial, agricultural and domestic sources. Regional differences in infection of the fish were noted along the length of the Elbe studied with highest prevalence occurring in heavily polluted areas. When the authors used a linear model to compare these regional differences in prevalence of infection with biological parameters, not all the differences observed could be attributed to Ligula. They proposed that pollution may have contributed to the observed altered reproductive and endocrine status observed in the fish. Whilst these studies in no way refute the observed effects on Ligula on the hypothalamus/pituitary gland/gonadal axis they do highlight the possible importance of other biological parameters such as water quality.

LIGULA: A MODEL FOR POLLUTION MONITORING

The association of water quality with the interaction between parasites and their fish hosts is not surprising as there have been recent studies which have highlighted the role of pollutants in host-parasite interactions (Hoole, 1997; Morley et al. 2006, Sures, $2008 a, b)$. Several studies have investigated the effects, not only of pollutants on the immune response of the fish hosts to the parasitic fauna (Hoole, 1997), but also on helminth life cycles. These latter studies have primarily concentrated on trematode stages such as eggs, miracidia, cercariae and metacercariae (Abd Allah et al. 1997; Morley et al. $2001 a, b, c$; 2002, 2003; Pietrock et al. 2002) and the bioaccumulation of heavy metals in adult acanthocephalans and cestodes in fish (Sures et al. 1997; Sures and Siddall, 1999; Sures, 2003). The relatively few studies which have been carried out on the interaction between fish tapeworms and heavy metals have indicated that these metazoan parasites possess, on some occasions, the ability to bio-accumulate pollutants at greater levels than their fish hosts. For example, the monozoic cestode, Monobothrium wageneri, had higher concentrations of both cadmium $(\mathrm{Cd})$ and lead $(\mathrm{Pb})$ than its host tench, Tinca tinca, whilst there was no difference between $\mathrm{Pb}$ burdens detected in the adult cestode, Bothriocephalus scorpii, and those present in the intestinal wall of its host turbot, Scophthalamus maximus (Sures et al. 1997). In addition, the concentration of heavy metals is dependent on the different body parts of tapeworms analysed. For example, posterior gravid proglottids of the cestode, Bothriocephalus scorpii accumulate higher contents of $\mathrm{Pb}$ and $\mathrm{Cd}$ than the anterior immature ones (Sures et al. 1997). This may be due to the ability of tapeworm egg shells to bio-accumulate heavy metals (Khalil et al. 2009).

The size and ubiquitous nature of Ligula has led to the large plerocercoid stage being considered as a possible model in the study of heavy metal contamination in water bodies. Tenora et al. (2000) utilised atomic absorption spectrometry to monitor lead, chromium and cadmium levels in L. intestinalis and Philometra ovata in the body cavity of three cyprind fish species (A. brama, R. rutilus, B. bjoer$k n a)$. All heavy metals studied bio-accumulated within the plerocercoid to a greater level than in the fish muscle. Further studies carried out by Tenora et al. (2002) also revealed that this ability to bio-accummulate heavy metals $(\mathrm{Pb}, \mathrm{Cd})$ was not restricted to the plerocercoid, as the adult $L$. intestinalis contained higher levels of these two metals than the definitive avian hosts. It would appear however, that the accumulation of heavy metals by the plerocercoid stage may be dependent on the age of the parasite. Barus et al. (2001) noted that whilst nickel levels were higher in young plerocercoids, the levels of the majority of heavy metals monitored, i.e. $\mathrm{Pb}, \mathrm{Cr}$ and $\mathrm{Cd}$, were greater in the older parasites. They hypothesised that this indicated that accumulation of heavy metals in the parasite was a gradual and long-term process which probably occurred during the growing phase of the parasite in the fish host. More recent studies by Tekin-Ozan and co-workers (Tekin-Ozan and Kir, 2005, 2008; Tekin-Ozan and Barlas, 2008), utilising Ligula and tench (Tinca tinca), have extended the greater bio-accummulation by the plerocercoid to a more extensive range of heavy metals and speculate that if the parasite reflects the amount of heavy metal contaminants in the water and sediments, it may provide reliable data about pollution in water bodies. Whilst this is perhaps debatable, the value of the association of the plerocercoid with heavy metals probably lies in the size of the parasite which may assist in the elucidation of how parasites can bioaccumulate pollutants with no apparent ill-effects on their biology. 
One important area that underpins all of the studies mentioned above relates to the taxonomic status of the parasites used, which are from a range of fish species and geographical locations. The classification of ligulid tapeworms into the genus Ligula Bloch, 1782 and genus Digramma Cholodkovsky, 1914 has proved controversial for many years, and yet L. intestinalis with its global distribution and complex life cycle may be a valuable model to study speciation and the evolution of parasite genetic diversity. Since the turn of the century there have been several investigations which have applied molecular techniques to studies on speciation within ligulid cestodes. Li and Liao (2003), using sequences for the $5^{\prime}$ end of 4 genes, i.e. 28S ribosomal ribonucleic acid (28rRNA), mitrochondrial cytochrome c oxidase subunit 1 (CO1), nicotinamide adenine dinucleotide dehydrogenase subunit 1 (ND1) and the internal transcribed spacer of the nuclear ribosomal deoxyribonucleic acid (ITS1), noted that there was low genetic divergence in these in Ligula and Digramma and suggested that the two parasites should be considered as different species within the genus Ligula. These authors had previously utilised 28rRNA and CO1 isolated from formalin-fixed specimens of Ligula obtained from Qinghai-Tibet Plateau, Russia and England and proposed that the Chinese Ligula was within the same species as that occurring in Europe. Importantly, they proposed that geographic location, host affinity and host habitat were not reliable criteria to use in the classification of Ligula (Li et al. 2000). Olson et al. (2002) provided molecular evidence that Ligula occurring in gudgeon, and roach in Lough Neagh, Northern Ireland, were separate strains which may be reflected in their effect on host gonadal development. In addition, Ligula from minnow (Phoxinus phoxinus) from Wales resembled those from the Lough Neagh roach. The authors suggested that the existence of separate strains in Lough Neagh probably resulted from the introduction of roach and an increase in the number of the definitive host, the great crested grebe. Logan et al. (2004) highlighted that L. intestinalis from Turkey were genetically isolated from their European and Chinese counterparts. In a recent extensive study carried out by Bouzid et al. (2008a), the genetic variation within $L$. intestinalis obtained from 13 fish species originating from different localities i.e. Algeria, Australia, Canada, China, Czech Repubic, Estonia, Ethiopa, France, Germany, UK, Mexico, Poland, Russia, Tunisa and the Ukraine, was analysed using two mitochondrial genes, cytochrome oxidase 1 and cytochrome $\mathrm{B}$, and the nuclear sequence of intergenic transcribed 2 (ITS2). The authors proposed that the evolutionary patterns observed were determined at the local and global levels. At the local aspect, the migrating avian definitive host was thought to be important in preventing the establishment of genetic barriers, whilst on the global scale, genetically distinct clusters were observed. In addition, the authors noted that Ligula was split into two clades, termed A and B. Clade A contained samples from Tunisia and Europe and were obtained from 'derived cyprinids' (Abramis, Alburnus, Phoxinus, Rutilus and Scardinius), whilst Clade B was restricted to European, Algerian, Chinese and Australasian samples from 'basal cyprinid fish' (Barbus, Gobio and Rhodeus). Bouzid et al. (2008b), utilising L. intestinalis, also proposed that inter-simple sequence repeat markers was a rapid and inexpensive technique to define markers that could be used to assess genetic diversity. Recently, isolation and characterization of microsatellite loci have been used to understand the genetic complexity and diversity that occurs within the ligulids. After this technology was established as a useful tool in the case of L. intestinalis (Stefka et al. 2007), Stefka and co-workers in 2009 used 15 microsatellite loci to monitor the genetic differences in populations of $L$. intestinalis from a range of distant geographical locations in North America, Europe, Asia, Africa and Australasia. They noted a very high level of polymorphism and strong genetic structure in Ligula from these localities and proposed some very interesting reasons for this. For example, the existence of parasite subdivisions between Europe and Tunisia was due to the Mediterranean Sea effect which, although did not prevent migration of the avian definitive host, the fact that the adult tapeworm persists in the bird for only one week (Dubinina, 1966) would probably mean that the tapeworm was not transported between the two localities. In addition, they also suggested that the fish immune response may be a factor in determining host-specificity of the Ligula genotypic lineages. Unfortunately, most of the studies on the immune response to the plerocercoid stage have been carried out in roach. In a series of publications by Hoole and co-workers it was established that there is an intense cellular response to the parasite (Hoole and Arme, 1982, 1983a, $b$; Taylor and Hoole, 1989 a, b, 1993, 1994, 1995) which involved several specific and non-specific humoral components (Hoole and Arme, 1986, 1988; Williams and Hoole, 1992, 1995). However, even with the host response, substantial differences to Ligula infection occur in roach and gudgeon (Arme, 1997), again indicating possible genetic diversity of the parasite.

In conclusion, since the classical experiments carried out by J. D. Smyth in 1947, which revealed L. intestinalis as a model to study tapeworm development in vitro, this large metazoan parasite has proved an invaluable model not only for parasitologists in general, but endocrinologists, ecologists, geneticists, immunologists and in pollution studies. 
REFERENCES

Abd Allah, A. T., Wanas, M. Q. S. and Thompson, S. N. (1997). Effects of heavy metals on survival and growth of Biomphalaria glabrata Say (Gastropoda: Pulmonata) and interaction with Schistosome infection. Fournal of Molluscan Studies 63, 79-86.

Adamek, Z., Barus, V. and Prokes, M. (1996). Summer diet of roach (Rutilus rutilus) infested by Ligula intestinalis (Cestoda) plerocercoids in the Dalesice Reservoir (Czech Republic). Folia Zoologica 45, 347-354.

Antonopoulou, E., Mayer, I., Borg, B., Swanson, P., Murza, I. and Christoforov, O. (1999). Effects of testosterone on gonadotropins, testes, and plasma 17alpha, 20beta-dihydroxy-4-pregnene-3-one levels in postbreeding mature Atlantic salmon, Salmo salar, male parr. Fournal of Experimental Zoology 284, 425-436.

Arme, C. (1968). Effects of the plerocercoid larva of a pseudophyllidean cestode, Ligula intestinalis, on the pituitary gland and gonads of its host. Biological Bulletin 134, 15-25.

Arme, C. (1975). Tapeworm-host interactions. In Symbiosis (ed. Jennings, D. H. and Lee, D. L.), pp 505-532. Cambridge University Press, Cambridge.

Arme, C. (1997). Ligula intestinalis: interactions with the pituitary-gonadal axis of its fish host. Fournal of Helminthology 71, 83-84.

Arme, C., Griffiths, D. V. and Sumpter, J. P. (1982). Evidence against the hypothesis that the plerocercoid larva of Ligula intestinalis (Cestoda: Pseudophyllidea) produces a sex steroid that interferes with host reproduction. Fournal of Parasitology 68, 169-171.

Arme, C. and Owen, R. W. (1968). Occurrence and pathology of Ligula intestinalis infections in British fishes. Fournal of Parasitology 54, 272-280.

Aydogdu, A., Selver, M. and Cirak, V. K. (2008). Comparison of helminth species and their prevalence in rudd (Scardinius erythrophalmus L. 1758) in Golbasi Dam Lake and Kocadere Stream in Bursa Province of Turkey. Turkish Fournal of Veterinary and Animal Sciences 32, 389-393.

Barber, I. and Huntingford, F. A. (1996). Parasite infection alters schooling behaviour: Deviant positioning of helminth-infected minnows in conspecific groups. Proceedings of the Royal Society of London Series B-Biological Sciences 263, 1095-1102.

Barus, V. and Prokes, M. (1994). Parasite load of Ligula intestinalis plerocercoids in adult silverbream, Blicca bjoerkna. Helminthologia 31, 91-94.

Barus, V., Sebela, M. and Prokes, M. (1997). On the possible free-living phase of the Ligula intestinalis plerocercoids (Ligulidae). Helminthologia 34, 173-174.

Barus, V., Tenora, F. and Kracmer, S. (2000). Heavy metal $(\mathrm{Pb}, \mathrm{Cd})$ concentrations in adult tapeworms (Cestoda) parasitizing birds. Helminthologia 37, 131-136.

Barus, V., Tenora, F., Kracmar, S. and Prokes, M. (2001). Accumulation of heavy metals in Ligula intestinalis plerocercoids (Pseudophyllidea) of different age. Helminthologia 38, 29-33.

Bauer, O. N. and Stolyarov, V. P. (1961). Formation of the parasite fauna and parasitic diseases of fish in hydroelectric reservoirs. In: Parasitology of Fishes (ed. Dogiel, V. A., Petrushevski, G. K. and Polyanski, Y. L.), pp. 246-254. Oliver and Boyd, London.

Bean, C. W. and Winfield, I. J. (1989). Biological and ecological effects of a Ligula intestinalis (L.) infestation of the gudgeon, Gobio gobio (L.) in Lough Neagh, Northern Ireland. Fournal of Fish Biology 34, 135-147.

Bean, C. W. and Winfield, I. J. (1992). Influences of the tapeworm Ligula intestinalis (L.) on the spatial distributions of juvenile roach Rutilus rutilus (L.) and gudgeon Gobio gobio (L.) in Lough Neagh, Northern Ireland. Netherlands Fournal of Zoology 42, 416-429.

Berglund, I., Antonopoulou, E., Mayer, I. and Borg, B. (1995). Stimulatory and inhibitory effects of testosterone on testes in Atlantic salmon male parr. Fournal of Fish Biology 47, 586-598.

Black, G. A. and Fraser, J. M. (1984). Dynamics of Ligula intestinalis (L.) in Catastomus commersoni (Lacèpède). Fournal of Fish Biology 25, 139-146.

Bouzid, W., Lek, S., Mace, M., Ben Hassine, O. K., Etienne, R., Legal, L. and Loot, G. (2008b). Genetic diversity of Ligula intestinalis (Cestoda:

Diphyllobothriidea) based on analysis of inter-simple sequence repeat markers. Fournal of Zoological Systematics and Evolutionary Research 46, 289-296.

Bouzid, W., Stefka, J., Hypsa, V., Lek, S., Scholz, T., Legal, L., Ben Hassine, O. K. and Loot, G. (2008a). Geography and host specificity: Two forces behind the genetic structure of freshwater fish parasite Ligula intestinalis (Cestoda: Diphyllobothriidae). International Fournal for Parasitology 38, 1465-1479.

Britton, J. R., Jackson, M. C. and Harper, D. M. (2009). Ligula intestinalis (Cestoda: Diphyllobothriidae) in Kenya: a field investigation into host specificity and behavioural alterations. Parasitology 136, 1367-1373.

Brown, S. P., Loot, G., Grenfell, B. T. and Geugan, J. F. (2001). Host manipulation by Ligula intestinalis: accident or adaptation. Parasitology 123, 519-529.

Brown, S. P., Loot, G., Teriokhin, A., Brunel, A., Brune1, C. and Guegan, J. F. (2002). Host manipulation by Ligula intestinalis: a cause or consequence of parasite aggregation? International Fournal for Parasitology 32, 817-824.

Burrough, R. J. and Kennedy, C. R. (1979). The occurrence and natural alleviation of stunting in a population of roach, Rutilus rutilus (L.). Fournal of Fish Biology 15, 93-109.

Carreau, S., Bourguiba, S., Lambard, S., Galeraud-Denis, I., Genissel, C. and Levallet, J. (2002). Reproductive system: aromatase and estrogens. Molecular and Cellular Endocrinology 193, 137-143.

Carter, V., Pierce, R., Dufour, S., Arme, C. and Hoole, D. (2005). The tapeworm Ligula intesinalis (Cestoda: Pseudophyllidea) inhibits LH expression and puberty in its teleost host, Rutilus rutilus. Reproduction 130, 939-945.

Claridge, P. N., Hardisty, M. W., Potter, I. C. and Williams, C. V. (1985). Abundance, life history and ligulosis in the gobies (Teleosti) of the inner Severn estuary. Fournal of the Marine Biological Association of the United Kingdom 65, 951-968.

Cowx, I. G., Rollins, D. and Tumwebaze, R. (2008). Effect of Ligula intestinalis on the reproductive capacity of Rastrineobola argentea in Lake Victoria. Fournal of Fish Biology 73, 2249-2260. 
Crews, A. E. and Yoshino, T. P. (1989). Schistosoma mansoni: effect of infection on reproduction and gonadal growth in Biomphalaria glabrata. Experimental Parasitology 68, 326-334.

Cruz, M. and Canario, A. V. (1999). cDNA cloning and expression of brain and ovary aromatase in tilapia, Oreochromis mossambicus. Proceedings of the 6th International Symposium on the Reproductive Physiology of Fish, Bergen, Fuly 1999, 193.

Dejen, E., Vijverberg, J. and Sibbing, F. A. (2006). Spatial and temporal variation of cestode infection and its effects on two small barbs (Barbus humilis and Barbus tanapelagius) in Lake Tana, Ethiopa. Hydrobiologia 556, 109-117.

Dubinina, M. N. (1966). Tapeworms (Cestoda, Ligulidae) of the Fauna of the USSR. Moscow; Nauka Publishers, Translation 1980, Amerind, New Dehli.

Dufour, S., Delerue-Le Belle, N. and Fontaine, Y. A. (1983). Development of a heterologous radioimmunoassay for eel (Anguilla anguilla L.) gonadotropin. General and Comparative Endocrinology 49, 404-413.

Dufour, S., Weltzien, F.-A., Sebert, M.-E., Le Belle, N., Vidal, B., Vernier, P. and Pasqualini, C. (2005). Dopaminergic inhibition of reproduction in teleost fishes: ecophysiological and evolutionary implications. Annals of the New York Academy of Sciences 1040, 9-22.

Ergonul, M. B. and Altindag, A. (2005a). The effects of Ligula intestinalis plerocercoids on the growth features of tench, Tinca tinca. Turkish Fournal of Veterinary and Animal Sciences 29, 1337-1341.

Ergonul, M. B. and Altindag, A. (2005b). The occurrence and dynamics of Ligula intestinalis in its cyprinid fish host, tench Tinca tinca, in Morgan Lake (Ankara, Turkey). Veterinarni Medicina 50, 537-542.

Feist, G. and Schreck, C. B. (1996).

Brain-pituitary-gonadal axis during early development and sexual differentiation in the rainbow trout, Oncorhynchus mykiss. General and Comparative Endocrinology 102, 394-409.

Fenton, A. and Rands, S. A. (2006). The impact of parasite manipulation and predator foraging behavior on predator-prey communities. Ecology 87, 2832-2841.

Gonzalez, A. and Piferrer, F. (1999). Cytochrome p450 aromatase enzyme acivity and reproduction in teleost fish: studies in the European sea bass (Dicentrarchus labrax). Proceedings of the 6th International Symposium on the Reproductive Physiology of Fish, Bergen, Fuly 1999, $39-42$.

Groves, K. L. and Shields, B. A. (2001). Observations on the plerocercoid stage of the tapeworm Ligula in three species of fish from the lower Crooked River of central Oregon. Fournal of Aquatic Animal Health 13, 285-289.

Hajirostamloo, M. (2008). The occurrence and parasitehost of Ligula intestinalis in Sattarkhan Lake (East Azerbaijan-Iran). Fournal of Animal and Veterinary Advances 7, 221-225.

Harries, J. E., Janbakshs, A., Jobling, S., Matthiessen, P., Sumpter, J. P. and Tyler, C. R. (1999). Estrogenic potency of effluent from two sewage treatment works in the United Kingdom. Environmental Toxicology and Chemistry 18, 932-937.
Harries, J. E., Sheahan, D. A., Jobling, S., Matthiessen, P., Neall, P. R., Sumpter, J. P., Taylor, T. and Zaman, N. (1997). Estrogenic activity in five United Kingdom rivers detected by measurement of vitellogenesis in caged male trout. Environmental Toxicology and Chemistry 16, 535-542.

Harris, M. T. and Wheeler, A. (1974). Ligula infestation of bleak Alburnus alburnus (L.) in the tidal Thames. Fournal of Fish Biology 6, 181-188.

Hatice, T. K., Erdogan, Z. and Coz-rakovac, R. (2006) The occurrence of Ligula intestinalis (L.) observed in chub (Leuciscus cephalus L.) from Caparlipatlak Dam lake, Ivrindi-Balikesir, Turkey. Periodicum Biologorum 108, 183-187.

Hecker, M. and Karbe, L. (2005). Parasitism in fish - an endocrine modulator of ecological relevance? Aquatic Toxicology 72, 195-207.

Hecker, M., Sanderson, J. T. and Karbe, L. (2007). Suppression of aromatase activity in populations of bream (Abramis brama) from the river Elbe, Germany. Chemophere 66, 542-552.

Hernandez-Rauda, R., Otero, J., Rey, P., Rozas, G. and Aldegunde, M. (1996). Dopamine and serotonin in the trout (Oncorhynchus mykiss) pituitary: main metabolites and changes during gonadal recrudescence. General and Comparative Endocrinology 103, 13-23.

Holmes, J. C. and Bethel, W. M. (1972). Modification of the intermediate host behaviour by parasites. In Behavioural Aspects of Parasite Transmission (ed. Canning, E. W. \& Wright, C. A.). Fournal of the Linnean Society 51, 123-149.

Hoole, D. (1994). Tapeworm infections in fish: past and present problems. In Parasitic Diseases of Fish (ed. Pike, A. D. \& Lewis, J. W.), pp. 119-140. Samara Publishing Ltd, Tresaith, Dyfed.

Hoole, D (1997). The effects of pollutants on the immune response of fish: implications for helminths. Parassitologia 39, 219-225.

Hoole, D. and Arme, C. (1982). Ultrastructural studies on the cellular response of roach, Rutilus rutilus L., to the plerocercoid larva of the pseudophyllidean cestode, Ligula intestinalis. Fournal of Fish Diseases $\mathbf{5}$, 131-144

Hoole, D. and Arme, C. (1983a). Ligula intestinalis (Cestoda: Pseudophyllidea): An ultrastructural study on the cellular response of roach fry, Rutilus rutilus. International Fournal for Parasitolology 13, 359-363.

Hoole, D. and Arme, C. (1983b). Ultrastructural studies on the cellular response of fish hosts following experimental infection with the plerocercoid of Ligula intestinalis (Cestoda: Pseudophyllidea). Parasitology 87, 139-149.

Hoole, D. and Arme, C. (1985). The in vitro culture and tegumental dynamics of the plerocercoid of Ligula intestinalis (Cestoda: Pseudophyllidea). International Fournal for Parasitology 16, 609-615.

Hoole, D. and Arme, C. (1986). The role of serum leucocyte adherence to the plerocercoid of Ligula intestinalis (Cestoda: Pseudophyllidea). Parasitology 92, 413-424.

Hoole, D. and Arme, C. (1988). Ligula intestinalis (Cestoda: Pseudophyllidea): phosphorycholine inhibition of fish leucocyte adherence. Diseases of Aquatic Organisms 5, 29-33. 
Huang, Y. S., Schmitz, M., Le Belle, N., Chang, C. F., Querat, B. and Dufour, S. (1997). Androgens stimulate gonadotropin-II beta-subunit in eel pituitary cells in vitro. Molecular and Cellular Endocrinology 131, 157-166.

Izyumova, N. A. (1987). Parasitic Fauna of Reservoir Fishes of the USSR and its Evolution. Amerind Publishing Co. Pvt. Ltd, New Dehli.

Joose, J. and Van Elk, R. (1986). Trichobilharzia ocellata: physiological characterisation of giant growth, glycogen depletion, and absence of reproductive activity in the intermediate snail host, Lymnaea stagnalis. Experimental Parasitology 62, 1-13.

Juhasz, S. (1979). Studies on the nature of the protease inhibitor of Ligula intestinalis. Helminthologia 16, 293-298.

Kanamori, A., Kagawa, H. and Nagahama, Y. (1987). Gonadotropin receptors in the postovulatory ovary of amago salmon (Oncorhynchus rhodurus). General and Comparative Endocrinology 66, 210-217.

Kennedy, C. R. and Burrough, R. J. (1981). The establishment and subsequent history of a population of Ligula intestinalis in roach Rutilus rutilus (L.). Fournal of Fish Biology 19, 105-126.

Kennedy, C. R., Shears, P. C. and Shears, J. A. (2001). Long-term dynamics of Ligula intestinalis and roach Rutilus rutilus: a study of three epizootic cycles over thirty-one years. Parasitology 123, 257-269.

Kerr, T. (1948). The pituitary in normal and parasitised roach (Leuciscus rutilus). Quarterly Fournal of Microscopic Science 89, 129-137.

Khalil, M., Furness, D., Polwart, A. and Hoole, D. (2009). X-ray microanalysis (EDXMA) of cadmium-exposed eggs of Bothriocephalus acheilognathi (Cestoda: Bothriocephalidea) and the influence of this heavy metal on coracidial hatch and activity. International Fournal for Parasitology 39, 1093-1098.

Kir, I. and Tekin-Ozan, S. (2005). Occurrence of helminths in tench (Tinca tinca L., 1758) of Kovada (Isparta) Lake, Turkey. Bulletin of the European Association of Fish Pathologists 25, 75-81.

Lafferty, K. D. (1999). The evolution of trophic transmission. Parasitology Today, 12, 111-115.

Larralde, C., Morales, J., Terrazas, I., Govezensky, T. and Romano, M. C. (1995). Sex hormone changes induced by the parasite lead to feminization of the male host murine Taenia crassiceps cysticercosis. Fournal of Steriod Biochemistry and Molecular Biology 52, 575-580.

Li, J., Liao, X. and Yang, H. (2000). Molecular characterization of a parasitic tapeworm (Ligula) based on DNA sequences from formalin-fixed specimens. Biochemical Genetics 38, 309-322.

Li, J. J. and Liao, X. H. (2003). The taxonomic status of Digramma (Pseudophyllidea: Ligulidae) inferred from DNA sequences. Fournal of Parasitology 89, 792-799.

Lin, Y. C., Rikihisa, Y., Kono, H. and Gu, Y. (1990). Effects of larval tapeworm (Taenia taeniaeformis) infection on reproductive functions in male and female rats. Experimental Parasitology 70, 344-352.

Logan, F. J., Horák, A, Štefka, J., Aydogdu, A. and Scholz, T. (2004). The phylogeny of diphyllobothriid tapeworms (Cestoda: Pseudophyllidea) based on ITS-2 rDNA sequences. Parasitology Research 94, $10-15$.

Loot, G., Aulagnier, S., Lek, S., Thomas, F. and Guegan, J. F. (2002a). Experimental demonstration of a behavioural modification in a cyprinid fish, Rutilus rutilus (L.) induced by a parasite, Ligula intestinalis. Canadian Fournal of Zoology-Revue Canadienne de Zoologie 80, 738-744.

Loot, G., Brosse, S., Lek, S. and Guegan, J. F. (2001a). Behaviour of roach (Rutilus rutilus) altered by Ligula intestinalis (Cestoda: Pseudophyllidea): a field demonstration. Freshwater Biology 46, 1219-1227.

Loot, G., Fancisco, P., Santoul, F., Lek, S. and Guegan, J. F. (2001b). The three hosts of the Ligula intestinalis (Cestoda) life cycle in Lavernose-Lacasse gravel pit, France. Archiv für Hydrobiologie 152, 511-525.

Loot, G., Lek, S., Brown, S. P. and Guegan, J. F. (2001c). Phenotypic modification of roach (Rutilus rutilus L.) infected with Ligula intestinalis L. (Cestoda: Pseudophyllidea). Fournal of Parasitology 87, 1002-1010.

Loot, G., Lek, S., Dejean, D. and Guegan, J. F. (2001d). Parasite-induced mortality in three host populations of the roach Rutilus rutilus (L.) by the tapeworm Ligula intestinalis (L.). Annales de Limnologie - International Fournal of Limnology 37, 151-159.

Loot, G., Park, Y. S., Lek, S. and Brosse, S. (2006). Encounter rate between local populations shapes host selection in complex parasite life cycle. Biological fournal of the Linnean Society 89, 99-106.

Loot, G., Poulin, R., Lek, S. and Guegan, J. F. (2002b). The differential effects of Ligula intestinalis (L.) plerocercoids on host growth in three natural populations of roach, Rutilus rutilus (L.). Ecology of Freshwater Fish 11, 168-177.

Mahon, R. (1976). Effect of the cestode Ligula intestinalis on spottail shiners, Notropis hudsonius. Canadian Fournal of Zoology 54, 2227-2229.

Mataskasi, I. and Juhasz, S. (1977). Ligula intestinalis (L. 1758): Investigation on plerocercoids and adults for protease inhibitor activities. Parasitologia Hungarica 10, 51-60.

Matskasi, I. and Nemeth, I. (1979). Ligula intestinalis (Cestoda: Pseudophyllidea): Studies on the properties of proteolytic and protease inhibitor activities of the plerocercoid larvae. International Fournal for Parasitology 9, 27-33.

McMasters, M. E., Van der Kraak, G. J. and Munkittrick, K. R. J. (1996). An epidemiological evaluation of the biochemical basis for steroid hormonal depressions in fish exposed to industrial wastes. Great Lakes Research 22, 53-71.

Melamed, P., Rosenfeld, H., Elizur, A. and Yaron, Z. (1998). Endocrine regulation of gonadotropin and growth hormone gene transcription in fish. Comparative Biochemistry and Physiology. C: Comparative Pharmacology and Toxicology 119, 325-338.

Montero, M., Le Belle, N., Vidal, B. and Dufour, S. (1996). Primary cultures of dispersed pituitary cells from estradiol-pretreated female silver eels (Anguilla anguilla L.): immunocytochemical characterization of gonadotropic cells and stimulation of gonadotropin 
release. General and Comparative Endocrinology 104, 103-115.

Morgan, D. L. (2003). Distribution and biology of Galaxias truttaceus (Galaxiidae) in south-western Australia, including first evidence of parasitism of fishes in Western Australia by Ligula intestinalis (Cestoda). Environmental Biology of Fishes 66, 155-167.

Morley, N. J., Crane, M. and Lewis, J. W. (2001 a). Toxicity of cadmium and zinc to Diplostomum spathaceum (Trematoda: Diplostomidae) cercarial survival. International Fournal for Parasitology 31, 1211-1217.

Morley, N. J., Crane, M. and Lewis, J. W. (2001b). Toxicity of cadmium and zinc to encystment and in vitro excystment of Parorchis acanthus (Digenea: Philophthalmidae). Parasitology 122, 75-79.

Morley, N. J., Crane, M. and Lewis, J. W. (2001c). Toxicity of cadmium and zinc to miracidia of Schistosoma mansoni. Parasitology 122, 81-85.

Morley, N. J., Crane, M. and Lewis, J. W. (2002). Toxicity of cadmium and zinc mixtures to Diplostomum spathaceum (Trematode: Diplostomidae) cercarial survival. Archives of Environmental Contamination and Toxicology 43, 28-33.

Morley, N. J., Crane, M. and Lewis, J. W. (2003). Toxicity of cadmium and zinc to Diplostomum spathaceum (Trematode: Diplostomidae). Folia Parasitologica 122, 81-85.

Morley, N. J., Lewis, J. W. and Hoole, D. (2006). Pollutant-induced effects on immunological and physiological interactions in aquatic host-trematode systems: implications for parasite transmission. Fournal of Helminthology 80, 137-149.

Morrison, B. R. S. (1977). Observations on the tapeworm (Ligula intestinalis) a parasite of roach (Rutilus rutilus) in the lake of Menteith, Perthshire. Proceedings of the 8th British Coarse Fish Conference, 101-107.

Museth, J. (2001). Effects of Ligula intestinalis on habitat use, predation risk and catchability in European minnows. Fournal of Fish Biology 59, 1070-1080.

Nagahama, Y. (1999). Gonadal steroid hormones: major regulators of gonadal sex differentiation and gametogenesis in fish. Proceedings of the 6th International Symposium on the Reproductive Physiology of Fish, Bergen, fuly 1999, 211-221.

Nocillado, J. N. and Elizur, A. (2008). Neuroendocrine regulation of puberty in fish: insights from the grey mullet (Mugil cephalus) model. Molecular Reproduction and Development 75, 355-361.

Okubu, K. and Aida, K. (2001). Gonadotrophinreleasing hormones (GnRHs) in a primitive teleost, the arowana: phylogenetic evidence that three paralogous lineages of GnRH occurred prior to the emergence of teleosts. General and Comparative Endocrinology 124, $125-133$

Olson, P. D., Littlewood, D. T. L., Griffiths, D., Kennedy, C. R. and Arme, C. (2002). Evidence for the co-existence of separate strains or species of Ligula in Lough Neagh, Northern Ireland. Fournal of Helminthology 76, 171-174.

O’Neill, D. F., Powell, J. F., Standen, E. M., Youson, J. H., Warby, C. M. and Sherwood, N. M. (1998). Gonadotropin-releasing hormone $(\mathrm{GnRH})$ in ancient teleosts, the bonytongue fishes: putative origin of salmon GnRH. General and Comparative Endocrinology 112, 415-425.

Orr, T. S. C. (1968). Distribution and specificity of the plerocercoid of Ligula intestinalis (L) in the Northamptonshire area. Fournal of Helminthology XLII, 117-124.

Penlington, M. C., Williams, M. A., Sumpter, J. P., Rand-Weaver, M., Hoole, D. and Arme, C. (1997). Isolation and characterisation of mRNA encoding the salmon- and chicken-II type gonadotrophin-releasing hormones in the teleost fish Rutilus rutilus (Cyprinidae). Fournal of Molecular Endocrinology 19, 337-346.

Peter, R. E., Chang, J. P., Nahorniak, C. S., Omeljaniuk, R. J., Sokolowska, M., Shih, S. H. and Billard, R. (1986). Interactions of catecholamines and GnRH in regulation of gonadotropin secretion in teleost fish. Recent Progress in Hormone Research 42, 513-548.

Pietrock, M., Marcoliese, D. J. and McLaughlin, J. D. (2002). Effects of cadmium upon longevity of Diplostomum sp. (Trematoda: Diplostomidae) cercariae. Chemosphere 47, 29-33.

Pollard, D. A. (1974). The biology of a landlocked form of the normally catadromous Salmoniform fish Galaxius maculates (Jenyns). VI. Effects of cestode and nematode parasites. Australian Fournal of Marine and Freshwater Research 25, 105-120.

Richards, K. S. and Arme, C. (1981). The effects of the plerocercoid larva of the pseudophyllidean cestode Ligula intestinalis on the musculature of bream (Abramis brama). Zeitschrift für Parasitenkunde 65 , 207-215.

Sasi, H. (2005). Incidence of Ligula intestinalis from Transcaucasian barb. Indian Veterinary Fournal 82, 790-791

Shargh, S., Shamsaii, M. and Karimi, S. (2008). Distribution of parasitic cestode Ligula intestinalis in Mazandaran region. Iranian Fournal of Parasitology 3, 26-33.

Shields, B. A., Groves, K. L., Rombaugh, C. and Bellmore, R. (2002). Ligulosis associated with mortality in largescale suckers. Fournal of Fish Biology 61, 448-455.

Smyth, J. D. (1947). Studies on tapeworm physiology II Cultivation and development of Ligula intestinalis in vitro. Parasitology 48, 173-181.

Stefka, J., Gilleard, J. S., Grillo, V. and Hypsa, V. (2007). Isolation and characterization of microsatellite loci in the tapeworm Ligula intestinalis (Cestoda: Pseudophyllidea). Molecular Ecology Notes 7, 794-796.

Stefka, J., Hypsa, V. and Scholz, T. (2009). Interplay of host specificity and biogeography in the population structure of a cosmopolitan endoparasite: microsatellite study of Ligula intestinalis (Cestoda). Molecular Ecology 18, 1187-1206.

Sures, B. (2003). Accumulation of heavy metals by intestinal helminths in fish: an overview and perspective. Parasitology 126 (Suppl.), S53-S60.

Sures, B. (2008a). Environmental parasitology. Interactions between parasites and pollutants in the aquatic environment. Parasite 80, 434-438. 
Sures, B. $(2008 b)$. Host-parasite interactions in polluted environments. Fournal of Fish Biology 73, 1-10.

Sures, B. and Siddall, R. (1999). Pomphorhynchus laevis: the intestinal acanthocephalan as a lead sink for its fish host, chub (Leuciscus cephalus). Experimental Parasitology 93, 66-72.

Sures, B., Taraschewski, H. and Siddall, R. (1997). Heavy metal concentrations in adult acanthocephalans and cestodes compared to their fish hosts and to establish free-living bioindicators. Parassitologia 39, 213-218.

Sweeting, R. A. (1976). Studies on Ligula intestinalis (L.) effects in a roach population in a gravel pit. Fournal of Fish Biology 9, 515-522.

Sweeting, R. A. (1977). Studies on Ligula intestinalis, some aspects of the pathology in the second intermediate host. Fournal of Fish Biology 10, 43-50.

Szalai, A. J., Yang, X. and Dick, T. A. (1989). Changes in numbers and growth of Ligula intestinalis in the spottail shiner (Notropis hudsonius), and their roles in transmission. Fournal of Parasitology 75, 571-576.

Taylor, M. J. and Hoole, D. (1989a). Ligula intestinalis (L.) (Cestoda: Pseudophyllidea): plerocercoid-induced changes in the spleen and pronephros of roach, Rutilus rutilus (L.) and gudgeon, Gobio gobio. Fournal of Fish Biology 34, 583-528.

Taylor, M. J. and Hoole, D. (1989b). Ligula intestinalis (Cestoda: Pseudophyllidea): an ultrastructural study of the cellular response of roach fry, Rutilus rutilus, to an unusual intramuscular infection. Fournal of Fish Diseases 12, 523-528.

Taylor, M. J. and Hoole, D. (1993). Ligula intestinalis (L.) (Cestoda: Pseudophyllidea): polarization of cyprinid leucocytes as an indicator of host- and parasite-derived chemoattractants. Parasitology 107, 433-440.

Taylor, M. J. and Hoole, D. (1994). Modulation of fish lymphocyte proliferation by extracts and isolated proteinase inhibitors of Ligula intestinalis (Cestoda). Fish and Shellfish Immunology 4, 221-230.

Taylor, M. J. and Hoole, D. (1995). The chemiluminescence of cyprinid leucocytes in response to zymosan and extracts of Ligula intestinalis (Cestoda), Fish and Shellfish Immunology, 5, 191-198.

Tekin-Ozan, S. and Barlas, M. (2008). Concentrations of selected heavy metals in Ligula intestinalis L. 1758 plerocercoids (Cestoda) compared to it host's (Tinca tinca L. 1758) organs from Beysehir Lake (Turkey). Helminthologia 45, 76-80.

Tekin-Ozan, S. and Kir, I. (2005). Comparative study on the accumulation of heavy metals in different organs of tench (Tinca tinca L. 1758) and plerocercoids of its endoparasite Ligula intestinalis. Parasitology Research 97, 156-159.

Tekin-Ozan, S. and Kir, I. (2008). Concentrations of some heavy metals in tench (Tinca tinca 1., 1758), its endoparasite (Ligula intestinalis L., 1758), sediment and water in Beysehir Lake, Turkey. Polish Fournal of Environmental Studies 17, 597-603.

Tenora, F., Barus, V., Kracmer, S. and Dvoracek, J. (2000). Concentrations of some heavy metals in Ligula intestinalis plerocercoids (Cestoda) and
Philometra ovata (Nematoda) compared to some their hosts (Osteichthyes). Helminthologia 37, 15-18.

Tenora, F., Barus, V. and Prokes, M. (2002). Next remarks to the knowledge of heavy metal concentrations in gravid tapeworm species parasitizing aquatic birds. Helminthologia 39, 143-148.

Tobin, C. (1986). A record of Ligula intestinalis (L.) (Cestoda) from roach (Rutilus rutilus (L.)) in Lough Neagh. Irish Naturalists' Fournal 22, 78.

Trubiroha, A., Wuertz, S., Frank, S. N., Sures, B. and Kloas, W. (2009). Expression of gonadotropin subunits in roach (Rutilus rutilus, Cyprinidae) infected with plerocercoids of the tapeworm Ligula intestinalis (Cestoda). International Fournal for Parasitology 39, 1465-1473.

Trudeau, V. L. (1997). Neuroendocrine regulation of gonadotrophin II release and gonadal growth in the goldfish, Carassius auratus. Reviews of Reproduction 2 , 55-68.

Tyler, C. R., Santos, E. M. and Prat, F. (1999). Unscrambling the egg-cellular biochemical molecular and endocrine advances in oogenesis. Proceedings of the 6th International Symposium on the Reproductive Physiology of Fish, Bergen, Fuly 1999, 273-279.

Van Dobben, V. H. (1952). The food of the cormorant in the Netherlands. Adrea 40, 1-63.

Vidal, B., Pasqualini, C., Le Belle, N., Holland, M. C. H., Sbaihi, M., Vernier, P., Zohar, Y. and Dufour, S. (2004). Dopamine inhibits luteinizing hormone synthesis and release in the juvenile European eel: a neuroendocrine lock for the onset of puberty. Biology of Reproduction, 71, 1491-1500.

Weekes, P. J. and Penlington, B. (1986). First records of Ligula intestinalis (Cestoda) in rainbow trout, Salmo gairdneri, and common bully, Gobiomorphus cotidianus, in New Zealand. Fournal of Fish Biology 28, 183-190.

Williams, M. A. and Hoole, D. (1992). Antibody response of the fish Rutilus rutilus to the metacestode of Ligula intesinalis. Diseases of Aquatic Organisms 12, 83-89.

Williams, M. A. and Hoole, D. (1995). Immunolabelling of fish host molecules on the tegumental surface of Ligula intestinalis (Cestoda: Pseudophyllidea). International Fournal for Parasitology 25, 249-256.

Williams, M. A., Penlington, M. C., King, J. A., Hoole, D. and Arme, C. (1998). Ligula intestinalis (Cestoda) infections of roach (Rutilus rutilus) (Cyprinidae): immunocytochemical investigations into the salmon- and chicken-II type gonadotrophin-releasing hormone $(\mathrm{GnRH})$ systems in host brains. Acta Parasitologica 43, 232-235.

Wilson, R. S. (1971). The decline of a roach Rutilus rutilus (L.) population in Chew Valley Lake. Fournal of Fish Biology 3, 129-137.

Wyatt, R. J. and Kennedy, C. R. (1988). The effects of a change in the growth rate of roach, Rutilus rutilus (L.) on the population biology of the fish tapeworm Ligula intestinalis (L.). Fournal of Fish Biology 33, 45-57.

Wyatt, R. J. and Kennedy, C. R. (1989).

Host-constrained epidemiology of the fish tapeworm 
Ligula intestinalis (L.). Fournal of Fish Biology 35, 215-227.

Xianghua, L. and Zhixin, L. (1987). Distribution of ligulid tapeworms in China. Fournal of Parasitology 73, $36-48$.

Yan, L., Swanson, P. and Dickhoff, W. W. (1992). A two-receptor model for salmon gonadotropins
(GTH I and GTH II). Biology of Reproduction 47, 418-427.

Yu, K. L., He, M. L., Chik, C. C., Lin, X. W., Chang, J. P. and Peter, R. E. (1998). mRNA expression of gonadotropin-releasing hormones (GnRHs) and $\mathrm{GnRH}$ receptor in goldfish. General and Comparative Endocrinology 112, 303-311. 